\title{
EFFECT OF TEMPERATURE ON BTEX PERMEATION THROUGH HDPE AND FLUORINATED HDPE GEOMEMBRANES
}

\author{
R. Kerry Rowe ${ }^{\text {i) }}$, Toshifumi Mukunoki ${ }^{\text {ii) }}$ and Heather Lindsay ${ }^{\text {iii }}$
}

\begin{abstract}
The diffusion characteristics of high density polyethylene (HDPE) geomembranes with respect to hydrocarbons are investigated at temperatures of $22 \pm 1{ }^{\circ} \mathrm{C}$ and $6 \pm 1^{\circ} \mathrm{C}$. Results are reported for an aqueous solution of benzene, toluene, ethylbenzene, and xylene (BTEX). The partitioning coefficient obtained from sorption/immersion test is shown to be effectively the same as that from desorption test. Both conventional untreated (HDPE) and fluorinated (f-HDPE) geomembranes are examined and it is shown that a fluorinated layer on the surface of an HDPE geomembrane increases its resistance to the permeation of BTEX penetrants by about a factor of 2.4 at $22^{\circ} \mathrm{C}$ and 1.8 at $6^{\circ} \mathrm{C}$. An Arrhenius relationship is developed that could be used for estimating hydrocarbon permeation at different temperatures between $6^{\circ} \mathrm{C}$ and $22^{\circ} \mathrm{C}$ for both the HDPE and f-HDPE geomembranes examined.
\end{abstract}

Key words: BTEX, diffusion, fluorination, geomembrane, hydrocarbons, partitioning, permeation (IGC: M9)

\section{INTRODUCTION}

High density polyethylene (HDPE) geomembranes are used to minimize the migration of potentially hazardous contaminants because of their excellent performance as barriers against the leakage of fluids if properly designed and constructed (e.g., Rowe et al., 2004; Rowe, 2005; Mitchell et al.; 2007, Rowe et al.; 2009, Brachman and Sabir, 2010; Koerner et al., 2010). Provided that they can be maintained intact (i.e., without any holes) then contaminated liquids will be retained by the geomembrane. However, there is still the potential for contaminant migration by molecular diffusion through the geomembrane which could contaminate groundwater (Rowe, 1998; Edil, 2003; Rowe, 2005). In addition to traditional applications such as liners in municipal landfills where the geomembrane temperature is usually at or above $20^{\circ} \mathrm{C}$, there are also applications for geomembranes to control the migration of hydrocarbon contaminated groundwater and for the containment of hydrocarbon contaminated soil in situations where the geomembrane temperature is below the temperature at which most prior geomembrane diffusion testing has been conducted (i.e., room temperature of $20-24^{\circ} \mathrm{C}$ ). An example of a case where a composite liner comprised of a geomembrane and geosynthetic clay liner (GCL) was used to contain a hydrocarbon spill in Arctic was described by Bathurst et al. (2006). The effect of temperature on diffusion and sorption for the GCL component of the liner was reported by Rowe et al.
(2005) who compared parameters deduced at typical room temperature $\left(22^{\circ} \mathrm{C}\right)$ with those at the average summer temperature of $6^{\circ} \mathrm{C}$ measured at the site. This present paper looks at diffusion through the geomembrane component of that liner at the same two temperatures. While the temperatures examined were motivated by this specific field case, in fact the relevant temperature for many practical applications not involving municipal landfills or ash monofills lay between the two temperatures examined herein and hence it is expected that the results of this present study have much wider application than the specific case which motivated the study.

Diffusion through a geomembrane is characterized by three separate phases: adsorption, diffusion and desorption. The rate of mass transport through a geomembrane is affected by factors such as: the molecular structure of the HDPE (e.g., the level of cross-linking and crystallinity), polymer swelling, contaminant concentration, and temperature (Anand, 1994; Aminabhavi and Naik, 1998; D'Aniello et al., 2000). It is known that volatile organic contaminants readily diffuse through HDPE geomembrane liner at room temperature (Park and Nibras, 1993; Sangam and Rowe, 2001; Sangam and Rowe, 2005; Islam and Rowe, 2009). This has prompted the development of modified geomembranes that will provided a better barrier to hydrocarbons including co-extruded geomembranes (McWatters and Rowe, 2010) and fluorinated geomembranes as discussed below.

It is known that fluorination can substantially reduce

i) GeoEngineering Centre at Queen's-RMC, Queen's University, Canada (kerry@civil.queensu.ca).

ii) X-Earth Center, Department of Civil and Environmental Engineering, Graduate School of Science and Technology, Kumamoto University, Japan (mukunoki@kumamoto-u.ac.jp).

iii) AMEC Earth and Environmental, Mississauga, Ontario, Canada (heather.lindsay@amec.com).

The manuscript for this paper was received for review on February 8, 2011; approved on July 10, 2011.

Written discussions on this paper should be submitted before July 1, 2012 to the Japanese Geotechnical Society, 4-38-2, Sengoku, Bunkyo-ku, Tokyo 112-0011, Japan. Upon request the closing date may be extended one month. 
gas permeation (Mohr et al., 1991a, b) and the permeation of hydrocarbons (Sangam and Rowe, 2005) through a membrane. A fluorinated geomembrane (referred as f-HDPE, herein) is created by utilizing a surface fluorination technique that exchanges the hydrogen on the outer surface of the polymer chains of an HDPE geomembrane with elemental fluorine. The exchange of hydrogen and fluorine is a free radical substitutive reaction caused by the weakness of the fluorine-fluorine bond and the high strength of a carbon-fluorine bond (Anand et al., 1994). For the fluorinated geomembrane considered herein, surface fluorination was applied to both sides of the geomembrane. Surface fluorination decreases the permeation of hydrocarbons without affecting the physical properties of the geomembrane as less than $1 \%$ of the geomembrane is subjected to the treatment (Sangam et al., 2001).

Previous studies of factors relevant to the containment of hydrocarbon spills in the groundwater by a composite barrier walls have addressed the design and construction (Bathurst et al., 2006), diffusion through the GCL (Rowe et al., 2005) and the long-term performance (service life) of the geomembrane (e.g., Rowe et al., 2010). Thus the primary objectives of this paper are to examine the diffusive characteristics of the geomembrane at relevant temperatures by: (a) evaluating the permeation coefficients for selected hydrocarbons (benzene, toluene, ethylbenzene and xylene; BTEX) with respect to both HDPE and f-HDPE geomembranes at $22 \pm 1^{\circ} \mathrm{C}$ and $6 \pm 1^{\circ} \mathrm{C}$, (b) developing an Arrhenius relationships that could potentially be used to estimate the permeation characteristic at temperatures between 22 and $6^{\circ} \mathrm{C}$ based on data at room temperature $\left(22^{\circ} \mathrm{C}\right)$, and (c) comparing the effectiveness of the application of a fluorine layer to an HDPE geomembrane for two different f-HDPE geomembranes by comparing results from the present study with those obtained by Sangam and Rowe (2005) at room temperature $\left(22 \pm 1^{\circ} \mathrm{C}\right)$.

\section{BACKGROUND}

\section{Contaminant Permeation through a Polymer}

When an HDPE geomembrane is placed between two aqueous solutions one of which contains BTEX, creating a concentration gradient across the geomembrane, contaminants will permeate from the solution with the high concentration through the polymer to the solution of lower concentration. This permeation process is characterized by three different phases. First, the molecules partition to the adjacent surface of the polymeric material (adsorption), they then diffuse through the polymer matrix (diffusion), and finally they partition from the polymer to the outer solution (desorption) (Park and Nibras, 1993).

When in contact with dilute aqueous solutions under isothermal conditions, partitioning is proportional to the concentration (activity) of the solution and can be described by Henry's Law which relates the final equilibrium concentration in the polymer to the final equilibrium concentration of the surrounding solution (Aminabhavi and Naik, 1998), thus

$$
c_{\mathrm{g}}=S_{\mathrm{gf}} c_{\mathrm{f}}
$$

where: $c_{\mathrm{g}}=$ the final concentration at equilibrium in the polymer $\left[\mathrm{ML}^{-3}\right] ; S_{\mathrm{gf}}=$ partitioning coefficient [-] and $c_{\mathrm{f}}=$ final concentration in the contaminated (source) fluid adjacent to the geomembrane at equilibrium $\left[\mathrm{ML}^{-3}\right]$ (Sangam and Rowe, 2001).

Diffusion from dilute aqueous systems through a geomembrane is characterized by Fick's first law of diffusion (Crank, 1975) in which mass transport is proportional to the concentration gradient and there is a constant diffusion coefficient:

$$
j=-D_{\mathrm{g}} \frac{d c_{\mathrm{g}}}{d z}
$$

where $j=$ mass flux or mass transport per unit area $\left[\mathrm{ML}^{-2} \mathrm{~T}^{-1}\right] ; D_{\mathrm{g}}=$ diffusion coefficient in the geomembrane $\left[\mathrm{L}^{2} \mathrm{~T}^{-1}\right] ;\left(d c_{\mathrm{g}} / d z\right)=$ the concentration gradient in the geomembrane, and $z=$ the direction parallel to the concentration gradient.

In the transient state, diffusion is governed by Fick's second law, subject to the appropriate boundary and initial conditions (Crank, 1975):

$$
\frac{\partial c_{\mathrm{g}}}{\partial t}=D_{\mathrm{g}} \frac{\partial^{2} c_{\mathrm{g}}}{\partial z^{2}}
$$

Desorption is similar to the adsorption process only in reverse, whereby molecules partition from the polymeric matrix to the outer (receptor) fluid. This process is also described by Henry's Law:

$$
c_{\mathrm{g}}^{\prime}=S_{\mathrm{gfd}} c_{\mathrm{f}}^{\prime}
$$

where $c_{\mathrm{g}}^{\prime}$ and $c_{\mathrm{f}}^{\prime}$ are the final equilibrium concentrations in the polymer and receptor fluid respectively $\left[\mathrm{ML}^{-3}\right]$ and $S_{\text {gfd }}$ is the partitioning coefficient of the molecules from the polymer to the outer (receptor) fluid [-]. For aqueous solutes and water on either side of the geomembrane it is commonly assumed that $S_{\mathrm{gfd}}$ is equal to $S_{\mathrm{gf}}$ (Sangam and Rowe, 2001). In this paper, desorption tests will be performed and the validity of the common assumption that $S_{\mathrm{gfd}}=S_{\mathrm{gf}}$ will be evaluated.

It is difficult to measure and monitor concentration within the polymer itself during a permeation test. Thus, it is common practice to monitor the concentrations in the solutions adjacent to the geomembrane, observing that the concentration decreases in the source and increases in the receptor solutions with time. Combining Henry's law (Eq. (1)) and Fick's law (Eq. (3)), the diffusive flux through the geomembrane can be described by:

$$
j=-D_{\mathrm{g}} \frac{d c_{\mathrm{g}}}{d z}=-S_{\mathrm{gf}} D_{\mathrm{g}} \frac{d c_{\mathrm{f}}}{d z}=-P_{\mathrm{g}} \frac{d c_{\mathrm{f}}}{d z}
$$

where

$$
P_{\mathrm{g}}=S_{\mathrm{gf}} D_{\mathrm{g}}
$$

where $P_{\mathrm{g}}$, referred to as the permeation coefficient $\left[\mathrm{L}^{2} \mathrm{~T}^{-1}\right]$ (Rowe et al., 2004; Sangam and Rowe, 2005), accounts 
for the effects of both diffusion and partitioning (Aminabhavi and Naik, 1998).

\section{Arrhenius Model}

The temperature dependency of the diffusion coefficients may be modelled utilizing an Arrhenius relationship (Crank and Park, 1968).

$$
D_{\mathrm{T}_{1}}=A \exp \left(\frac{-E_{\mathrm{D}}}{R T}\right)
$$

where $A=$ Constant $\left[\mathrm{L}^{2} \mathrm{~T}^{-1}\right] ; \quad E_{\mathrm{D}}=$ Activation Energy $\left[\mathrm{Jmol}^{-1}\right] ; R=$ the universal Gas Constant $\left[\mathrm{Jmol}^{-1} \mathrm{~K}^{-1}\right]$; $T=$ Temperature $[\mathrm{K}]$. Equation (7) can be used to convert the diffusion coefficient, $D_{\mathrm{T}_{1}}$, at some reference temperature, $T_{1}$, to that at a second known temperature, $T_{2}$, as follows:

$$
\frac{D_{\mathrm{T}_{1}}}{D_{\mathrm{T}_{2}}}=\exp \left(\frac{E_{\mathrm{D}}}{R T_{2}}-\frac{E_{\mathrm{D}}}{R T_{1}}\right)
$$

or

$$
D_{\mathrm{T}_{1}}=D_{\mathrm{T}_{2}} \exp \left(\frac{E_{\mathrm{D}}}{R T_{1} T_{2}}\left(T_{1}-T_{2}\right)\right)
$$

Modelling environmental systems often involves temperatures in the range of $0{ }^{\circ} \mathrm{C}$ to $35^{\circ} \mathrm{C}$. Within this temperature range it may be assumed that $E_{\mathrm{D}} / R T_{1} T_{2}$ will remain relatively constant and the Arrhenius relationship may be simplified to the following (Schnoor, 1996):

$$
D_{\mathrm{T}_{1}}=D_{\mathrm{T}_{2}} \theta^{\left(\mathrm{T}_{1}-\mathrm{T}_{2}\right)}
$$

where $\theta=$ constant temperature coefficient that lies within the range of 1.0-1.10. In this paper, $\theta$ will be deduced for diffusion and partitioning coefficients based on data at two different temperatures.

\section{MATERIALS, TEST METHOD AND ANALYTICAL METHOD}

\section{Geomembranes}

The materials investigated were a conventional $1.5 \mathrm{~mm}$ thick HDPE geomembrane (referred herein as HDPE) and a $1.5 \mathrm{~mm}$ fluorinated HDPE (referred herein as f-HDPE) geomembrane. Both the HDPE and f-HDPE geomembranes were provided by Fluoroseal Inc. (Texas). The base geomembrane was the same in each case although there was some change in the f-HDPE geomembrane (a small increase in crystallinity and decrease in stdOIT) due to the temperature of the fluorination process (Table 1). The thickness of fluorinated layer was obtained by cutting a cross-section of the f-HDPE with a razor blade, applying a thin sputter-deposited gold coating, and then examining the section using a scanning electron microscopy combined with energy dispersive X-ray (SEM/EDX) spectroscopy. The thickness of the fluorinated layer on the f-HDPE geomembrane samples examined was variable and ranged between 1-4 $\mu \mathrm{m}$ with an average value (used in modelling) of $2.5 \mu \mathrm{m}$. This may be compared with a different f-HDPE geomembrane examined by Sangam and Rowe (2005) which had a thickness
Table 1. Properties of HDPE geomembranes tested

\begin{tabular}{lcc}
\hline \multicolumn{1}{c}{ Properties } & $\begin{array}{c}\text { HDPE } \\
\text { geomembrane }\end{array}$ & $\begin{array}{c}\text { f-HDPE } \\
\text { geomembrane }\end{array}$ \\
\hline Thickness & $1.5 \mathrm{~mm}$ & $1.5 \mathrm{~mm}$ \\
Crystallinity & $50 \%$ & $54 \%$ \\
Std-Oxidative Induction Time & $135 \mathrm{Minutes}$ & $110 \mathrm{Minutes}$ \\
Density & $950 \mathrm{~kg} / \mathrm{m}^{3}$ & $950 \mathrm{~kg} / \mathrm{m}^{3}$ \\
\hline
\end{tabular}

Table 2. Chemical properties tested

\begin{tabular}{lccccc}
\hline Chemical & $\begin{array}{c}\text { Molecular } \\
\text { Weight } \\
{[\mathrm{g} / \mathrm{mol}]}\end{array}$ & $\begin{array}{c}\text { Density* } \\
{[\mathrm{g} / \mathrm{mL}]}\end{array}$ & $\begin{array}{c}\text { Molecular } \\
\text { Volume** } \\
{\left[\mathrm{cm}^{3}\right]}\end{array}$ & $\begin{array}{c}\text { Solubility* } \\
{[\mathrm{mg} / \mathrm{L}]}\end{array}$ & $\begin{array}{c}\text { Log } \\
K_{\mathrm{ow}}^{*}\end{array}$ \\
\hline Benzene & 78.11 & 0.8786 & 88.90 & 1780 & 2.13 \\
Toluene & 92.14 & 0.8669 & 106.28 & 515 & 2.79 \\
Ethylbenzene & 106.17 & 0.8670 & 122.46 & 140 & 3.13 \\
m-Xylene & 106.17 & 0.8642 & 122.85 & 158 & 3.19 \\
p-Xylene & 106.17 & 0.8611 & 123.30 & 200 & 3.19 \\
o-Xylene & 106.17 & 0.8801 & 122.47 & 152 & 3.13 \\
\hline
\end{tabular}

* From Montgomery and Welkom (1989)

** Based on chemical density and Molecular Weight

of the fluorinated layer ranging from 1 to $5 \mu \mathrm{m}$ with an average value of $4 \mu \mathrm{m}$ as discussed later.

\section{Contaminants, Standards and Quality Controls}

Five volatile organic compounds-benzene, toluene, ethylbenzene, $\mathrm{m}$ and $\mathrm{p}$ and o-xylenes (BTEX)-with properties as given in Table 2 were examined. BTEX are common constituents of gasoline and diesel fuels. Tests were performed using a dilute aqueous solution of chemical grade chemicals ( $99.8 \%$ pure) purchased from Fisher Chemicals.

A Varian Gas Chromatography/Mass Spectrometer (GC/MS) system consisting of a Saturn $2000 \mathrm{MS}$ and $3800 \mathrm{GC}$ and $8200 \mathrm{CX}$ auto sampler was used to identify and quantify the concentrations of the contaminants investigated. The source solution for the permeation tests was prepared the day prior to the commencement of the experiments by dilution of a stock solution containing a 1 $\mathrm{g} / \mathrm{L}$ mixture of BTEX dissolved in distilled and deionized water (referred as DDW, herein). Then $0.67 \mathrm{~mL}$ of stock solution was added to $250 \mathrm{~mL}$ of DDW. The container was then sealed with a Teflon lid and refrigerated, allowing sufficient time for the solute and solvent to become completely mixed.

To monitor the quality and performance of the GC/MS, BTEX standard solutions of $1 \mathrm{mg} / \mathrm{L}$ and blanks were used for each round of testing. Blanks, consisting of $1 \%$ methanol and DDW were run at least every 10 vials to evaluate the performance of GC/MS throughout the run and check for any minor contamination. Two different BTEX standards were run that were of different known concentrations to verify and check the output data for the test series.

The accuracy and precision of the GC/MS were examined by creating one standard of a known concentration and running eight vials of the solution through the 


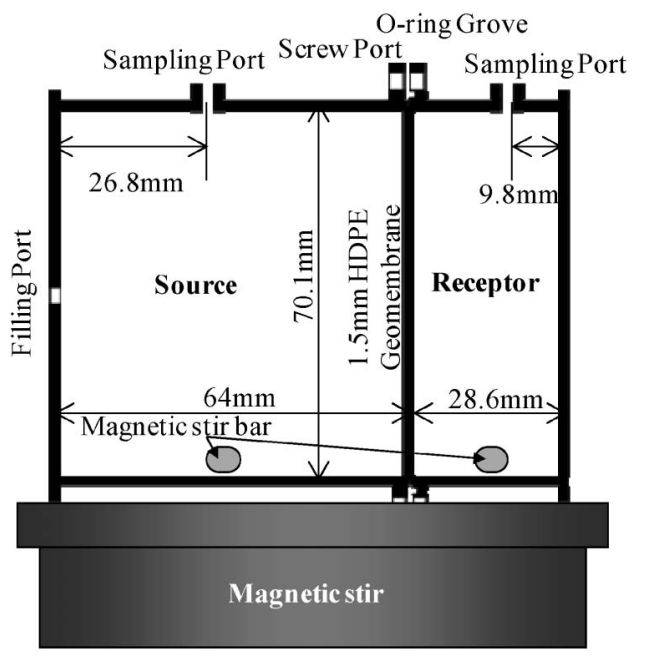

Fig. 1. Schematic of the permeation test system

GC/MS and the mean value, standard deviation, and detection limit were calculated. The detection limit for BTEX was established to be between $6 \mu \mathrm{g} / \mathrm{L}-12 \mu \mathrm{g} / \mathrm{L}$ depending on the compound examined.

\section{Permeation Tests}

Figure 1 schematically shows the entire system used for a permeation experiments conducted in this study. The permeation cells were stainless steel and consisted of a source and receptor separated by an HDPE or f-HDPE geomembrane. A magnetic stir bar was placed in the source and receptor reservoir to mix the solution and provide homogeneous concentrations in each reservoir. The flange of the receptor consisted of three grooves and flanges which were used to secure the $70 \mathrm{~mm}$ diameter geomembrane that separated the source and the receptor to ensure no side wall leakage. The receptor portion of the cell was initially filled with contaminant free DDW. The source was then filled with the dilute BTEX solution with an initial concentration of $2.5 \mathrm{mg} / \mathrm{L}$ for each case. Once the cell was secured, initial samples were immediately taken and the concentrations in the source and receptor were monitored with time. The permeation cells were placed such that the geomembrane was vertical, ensuring fluid contact on either side of the geomembrane and avoiding contact between the stirring bars and geomembrane.

\section{Sorption and Desorption Tests}

In a sorption/immersion test, the geomembrane is immersed in an aqueous solution containing the BTEX compounds of interests with an initial concentration of $2.5 \mathrm{mg} / \mathrm{L}$ for each compound and the decrease in concentration with time is monitored until equilibrium is reached. The results from the sorption/immersion tests were interpreted to give the partitioning parameter between aqueous solution and the geomembrane, $S_{\mathrm{gf}}$, using the approach described by Sangam and Rowe (2001).

In their interpretation of permeation experiments, Sangam and Rowe (2001) hypothesized that sorption and desorption were governed by the same parameter $\left(S_{\mathrm{gf}}\right)$. To examine that hypothesis, in this study, desorption tests were also performed. First, an immersion test was performed with the HDPE geomembrane being placed in a vial with each individual BTEX compound. The uptake mass of BTEX into the geomembrane coupons was measured regularly. As soon as the uptake mass reached steady state, each HDPE geomembrane coupon was moved into a $40 \mathrm{~mL}$ bottle filled with DDW to conduct a desorption test. The partitioning parameter obtained from the desorption test, denoted as $S_{\text {gfd }}$, can be expressed by:

$$
C_{\mathrm{GRE}}=S_{\mathrm{gfd}} C_{\mathrm{sF}}
$$

where $C_{\mathrm{sF}}$ is a residual concentration for each BTEX compounds in the DDW solution at the equilibrium state of desorption test and $C_{\mathrm{GRE}}$ is the concentration of residual BTEX in the geomembrane. If $M_{\mathrm{E} 0}$ is the initial mass of BTEX in the geomembrane, then after the desorption immersion test the contaminant mass balance at equilibrium can be written as:

$$
M_{\mathrm{E} 0}=M_{\mathrm{sF}}+M_{\mathrm{GRE}}+M_{\mathrm{R}}
$$

where $M_{\mathrm{sF}}$ is the final mass of contaminant in the DDW solution, $M_{\mathrm{GRE}}$ is the residual mass of contaminant in the geomembrane, and $M_{\mathrm{R}}$ is the mass removed by sampling events. $M_{\mathrm{E} 0}$ can be measured before starting the desorption test by subtracting the initial mass from the mass at the end of the immersion tests for each geomembrane coupon. Expressing the masses in terms of respective concentrations and volumes, Eq. (12) becomes:

$$
M_{\mathrm{E} 0}=C_{\mathrm{sF}} V_{\mathrm{sF}}+\frac{M_{\mathrm{G}}}{\rho_{\mathrm{G}}} C_{\mathrm{GRE}}+\sum V_{\mathrm{i}} C_{\mathrm{i}}
$$

$V_{\mathrm{sF}}$ is the volume of DDW solution at the equilibrium state; $M_{\mathrm{G}}$ and $\rho_{\mathrm{G}}$ are mass and density of geomembrane coupon and; $\Sigma V_{\mathrm{i}} C_{\mathrm{i}}$ is the mass removed at each sampling event. $S_{\text {gfd }}$ can then be obtained from Eqs. (11)-(13) as:

$$
S_{\mathrm{gfd}}=\frac{\left[M_{\mathrm{E} 0}-C_{\mathrm{SF}} V_{\mathrm{sF}}-\sum C_{\mathrm{i}} V_{\mathrm{i}}\right] \rho_{\mathrm{G}}}{M_{\mathrm{G}} C_{\mathrm{sF}}}
$$

\section{RESULTS}

\section{Partitioning Coefficient, $S_{\mathrm{gf}}$ and $S_{\mathrm{gfd}}$}

Sorption and desorption tests at $22^{\circ} \mathrm{C}$ were performed seven times to evaluate $S_{\mathrm{gf}}$ from sorption tests and twice to evaluate $S_{\text {gfd }}$ from desorption test. Figures 2 and 3 show typical variations in the BTEX concentrations with time in sorption and desorption tests respectively. In the immersion/sorption tests (e.g., Fig. 2), the magnitude of the decrease in the reservoir concentration at equilibrium was controlled by $S_{\mathrm{gf}}$. Benzene had the smallest drop in concentration of all the contaminants, reaching about $45 \%$ of the initial concentration. $m$ and $p$-Xylene experienced the most pronounced decrease in concentration dropping to less than $10 \%$ of the initial concentration. The $S_{\mathrm{gf}}$ values, estimated using the approach described by Sangam and Rowe (2001), are given in Table 3. 


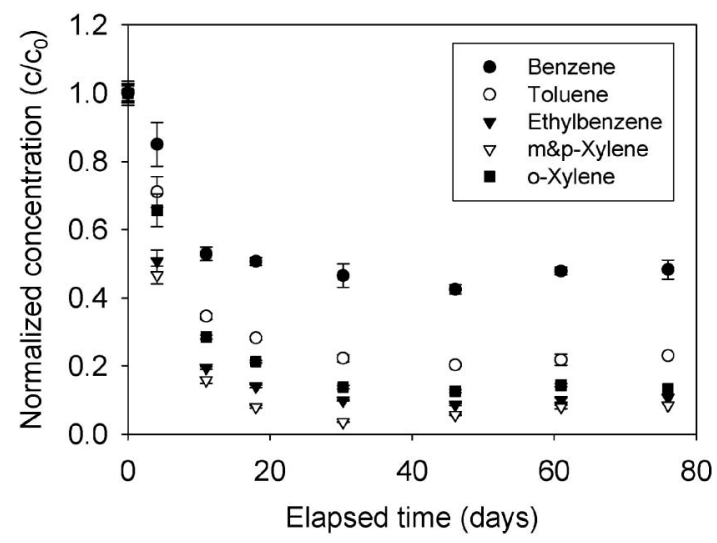

Fig. 2. Typical variation in BTEX concentrations with time in a sorption test (mean value and standard deviation of 3 samples)

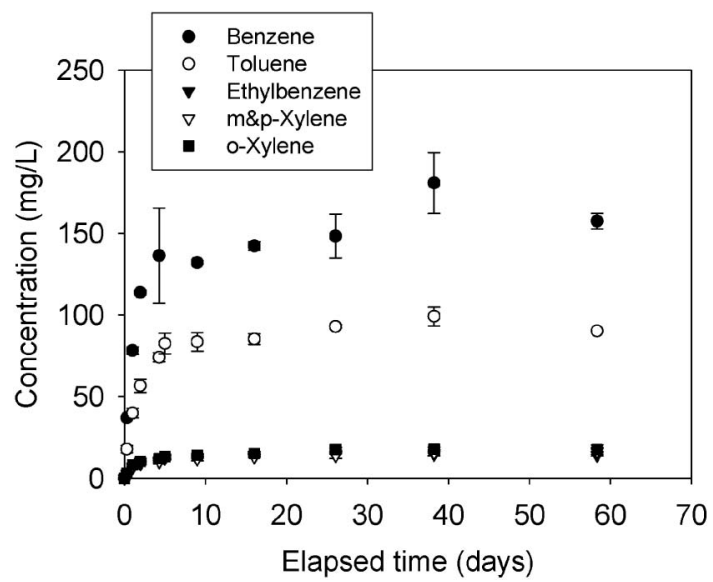

Fig. 3. Typical variation in BTEX concentrations with time in a desorption test (mean value and standard deviation of 3 samples)

Benzene had the least drop in concentration in the sorption tests (i.e., the lowest value of $S_{\mathrm{gf}}$ ) and consequently exhibited the greatest increase in concentration of all compounds in a desorption tests as shown in Fig. 3. The values of $S_{\text {gfd }}$, deduced (Eq. (14)) from the residual concentration of each BTEX compound in the DDW (e.g., Fig. 3) are given in Table 3. Comparing the results for $S_{\mathrm{gf}}$ and $S_{\mathrm{gfd}}$ (Table 3), the greatest difference in partitioning coefficient was for $\mathrm{m}$ and $\mathrm{p}$ Xylene (which also had the greatest uncertainty in $S_{\text {gfd }}$ based on two tests) followed by o-xylene. However, generally there was no statistically significant difference between the $S_{\mathrm{gfd}}$ and $S_{\mathrm{gf}}$ and it was concluded that to all practical purposes $S_{\mathrm{gfd}}$ may be taken as equal to $S_{\mathrm{gf}}$ for the interpretation of the permeation experiments.

Table 4 provides a comparison of the partitioning coefficient obtained from the sorption/immersion test at $6^{\circ} \mathrm{C}$ with those performed at $22^{\circ} \mathrm{C}$. Except for benzene, the ratio of mean $S_{\mathrm{gf}}$ at $6^{\circ} \mathrm{C}$ to $22^{\circ} \mathrm{C}$ was between 0.69 and 0.76 . The variability for benzene was greater (mean ratio of 0.58 ) but this may be due to the greater uncertainty associated with the mean values (as is evident by the larger coefficient of variation) for benzene. In all cases the
Table 3. Partitioning coefficients obtained from sorption and desorption tests at $22^{\circ} \mathrm{C}$ : mean value (standard deviation in brackets)

\begin{tabular}{crr}
\hline & \multicolumn{1}{c}{$S_{\mathrm{gf}}$} & \multicolumn{1}{c}{$S_{\mathrm{gfd}}$} \\
\hline Benzene & $36(+7)$ & $30(+0.7)$ \\
Toluene & $121(+14)$ & $114(+21.9)$ \\
ETB & $309(+8)$ & $325(+3.5)$ \\
m and p-Xylene & $337(+3)$ & $412(+69.3)$ \\
o-Xylene & $243(+25)$ & $349(+45.3)$ \\
\hline
\end{tabular}

Table 4. Partitioning coefficients obtained from sorption immersion tests at $6^{\circ} \mathrm{C}$ and $22^{\circ} \mathrm{C}$

\begin{tabular}{crr}
\hline & $S_{\mathrm{gf}}$ at $6^{\circ} \mathrm{C}$ & $S_{\mathrm{gf}}$ at $22^{\circ} \mathrm{C}$ \\
\hline Benzene & $21(+5)$ & $36(+7)$ \\
Toluene & $87(+6)$ & $121(+14)$ \\
ETB & $214(+28)$ & $309(+8)$ \\
m and p-Xylene & $247(+3)$ & $337(+3)$ \\
o-Xylene & $184(+3)$ & $243(+25)$ \\
\hline
\end{tabular}

results clearly show a decrease in $S_{\mathrm{gf}}$ with a decrease in temperature from $22^{\circ} \mathrm{C}$ to $6^{\circ} \mathrm{C}$.

\section{PERMEATION EXPERIMENTS}

\section{HDPE Geomembrane}

Permeation experiments were performed at $22^{\circ} \mathrm{C} \pm$ $1{ }^{\circ} \mathrm{C}$ and $6^{\circ} \mathrm{C} \pm 1^{\circ} \mathrm{C}$ for a period of 110 days. Contaminant concentrations were measured from the source and the receptor and analyzed in triplicate. Results obtained for the HDPE geomembrane at $22^{\circ} \mathrm{C}$ and $6^{\circ} \mathrm{C}$ are shown as normalized source and receptor concentrations plotted against time for the five contaminants in Figs. 4 to 8 . The points shown represent the mean of the three data points divided by the mean measured initial concentration of the source and the error bars show the standard deviation of the data set divided by the mean initial source concentration. The solid and dotted lines represent the calculated curves to be discussed later.

The results of the permeation experiments (Figs. 4 to 8) show a decrease in the source concentration with time while the receptor concentration increased as contaminants diffused through the geomembrane. There was a significant drop, with time, in the source concentration for all the contaminants due to both partitioning to the geomembrane and diffusion through the geomembrane to the receptor reservoir. Of all the contaminants, benzene exhibited the smallest drop in source concentration with the source being about $45 \%$ of the initial concentration at the end of the test shown. $m$ and $p$ Xylene experienced the most pronounced decrease in source concentration, dropping to less than $10 \%$ of the initial concentration in the same period of time. Except for benzene, the experiments at $22^{\circ} \mathrm{C}$ were either at, or very close to, equilibrium between the source, receptor and geomembrane in 110 days when they were terminated. The contaminants which experienced a large decrease in their source solution also exhibited a low rate of increase in the receptor concentration implying significant partitioning of these con- 


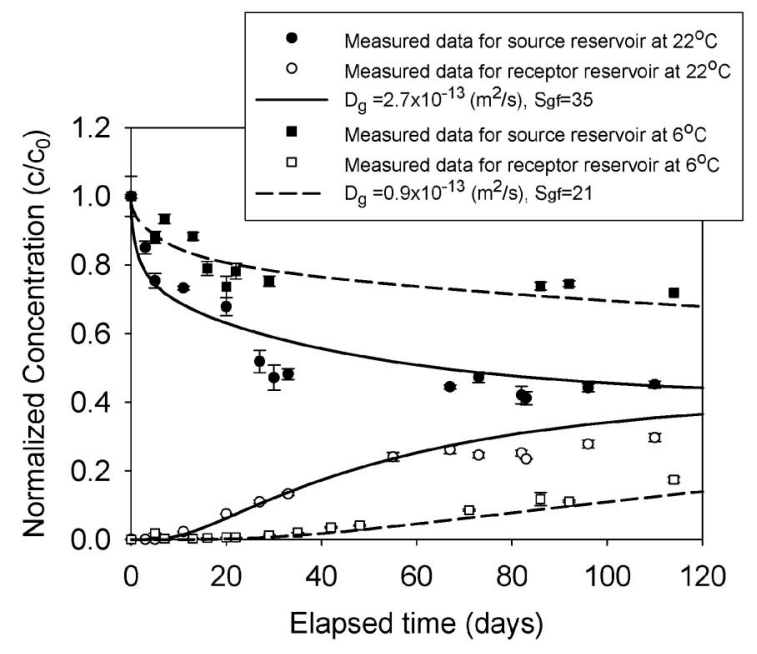

Fig. 4. Variation in benzene concentration in source and receptor cells for a permeation test on an HDPE geomembrane at $22^{\circ} \mathrm{C}$ and $6^{\circ} \mathrm{C}$ (mean value and standard deviation of 3 samples)

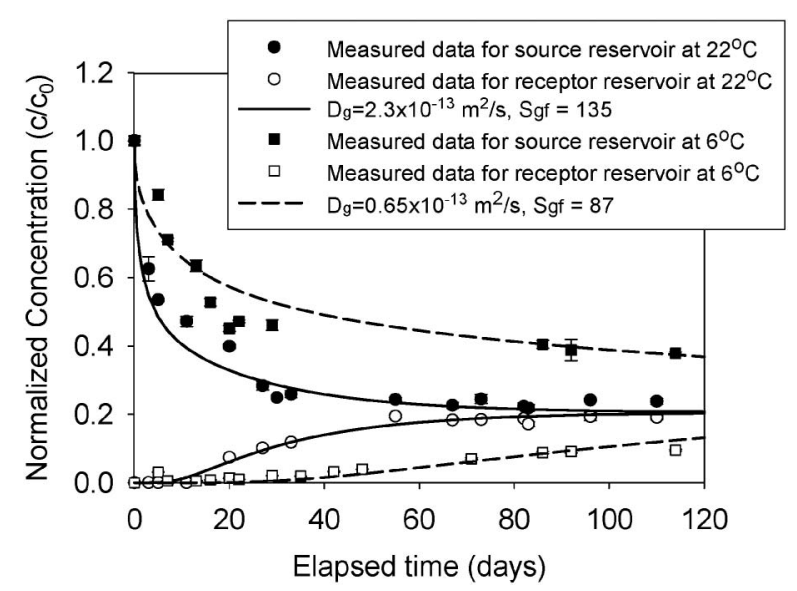

Fig. 5. Variation in toluene concentration in source and receptor cells for a permeation test on an HDPE geomembrane at $22^{\circ} \mathrm{C}$ and $6^{\circ} \mathrm{C}$ (mean value and standard deviation of 3 samples)

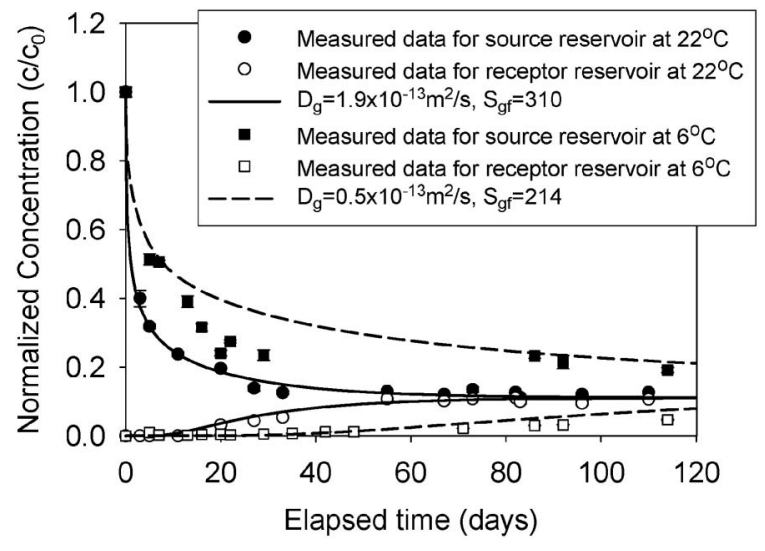

Fig. 6. Variation in ethylbenzene concentration in source and receptor cells for a permeation test on an HDPE geomembrane at $22^{\circ} \mathrm{C}$ and $6^{\circ} \mathrm{C}$ (mean value and standard deviation of 3 samples)

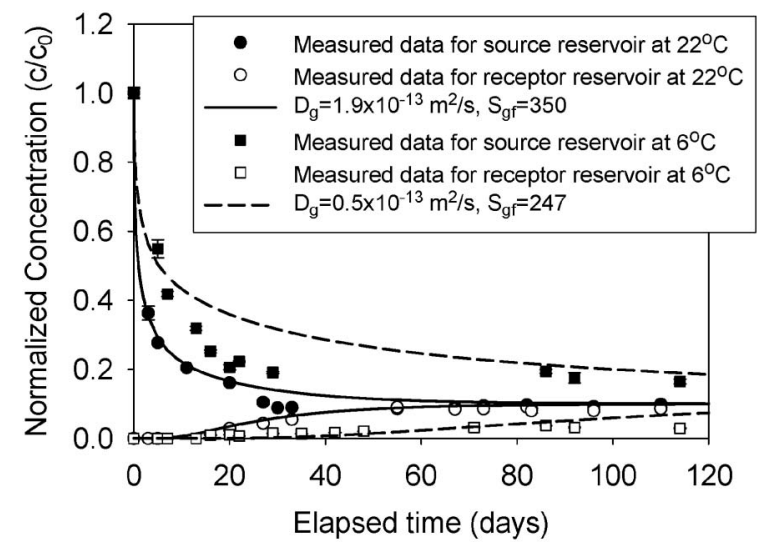

Fig. 7. Variation in $m$ and $p$-Xylene concentration in source and receptor cells for a permeation test on an HDPE geomembrane at $22^{\circ} \mathrm{C}$ and $6^{\circ} \mathrm{C}$ (mean value and standard deviation of 3 samples)

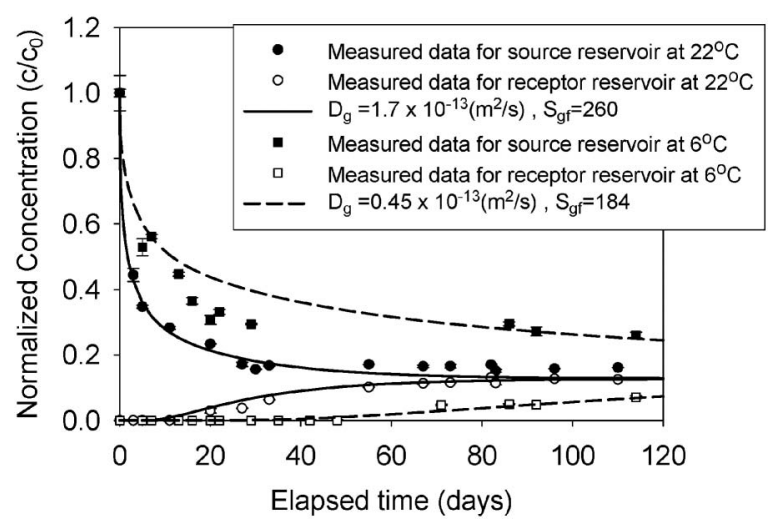

Fig. 8. Variation in o-Xylene concentration in source and receptor cells for a permeation test on an HDPE geomembrane at $22^{\circ} \mathrm{C}$ and $6^{\circ} \mathrm{C}$ (mean value and standard deviation of 3 samples)

taminants to the geomembrane from the aqueous solution. The data from the experiments at $6^{\circ} \mathrm{C}$ followed similar trends to those at $22^{\circ} \mathrm{C}$ but at a much slower rate with none of the contaminants approaching equilibrium between the source and receptor in the 110 days before termination (in contrast to those at $22^{\circ} \mathrm{C}$ as noted above). It can be visually inferred from Figs. 4-8 that temperature had a significant effect on both the diffusion coefficient, $D_{\mathrm{g}}$, and partitioning coefficient, $S_{\mathrm{gf}}$.

\section{F-HDPE Geomembrane}

The experimental data for f-HDPE geomembranes exhibited similar trends to those discussed for the HDPE geomembranes as shown in Figs. 9 to 13. Again the most significant drop in concentration was observed for $\mathrm{m}$ and p-Xylene which decreased to $13 \%$ of the initial normalized concentration by the time equilibrium was reached. The equilibrium concentrations were the same for both the HDPE and f-HDPE geomembranes indicating that the sorption was the same for both the f-HDPE and HDPE geomembranes. However, the rate of the decrease in normalized source concentration and increase in normalized receptor concentration for f-HDPE geomem- 


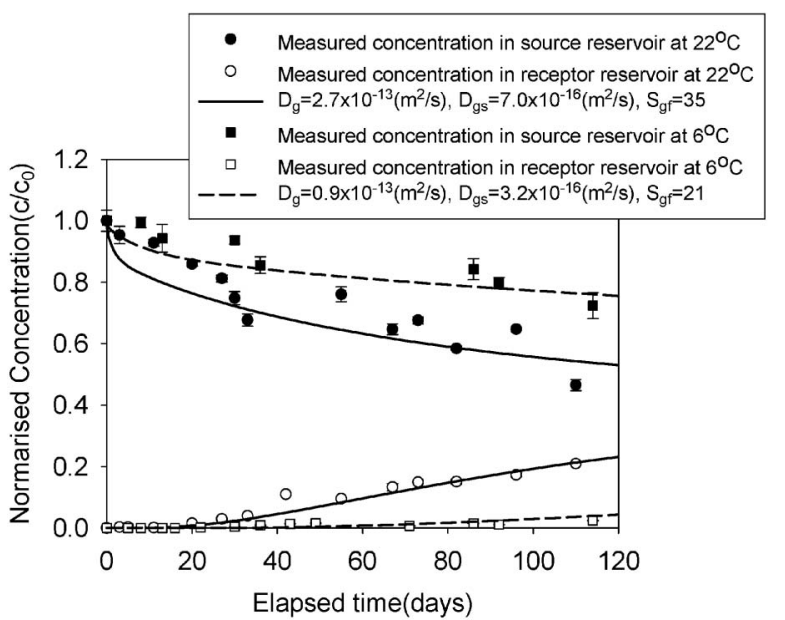

Fig. 9. Variation in benzene concentration in source and receptor cells for a permeation test on a f-HDPE geomembrane at $22^{\circ} \mathrm{C}$ and $6^{\circ} \mathrm{C}$ (mean value and standard deviation of 3 samples)

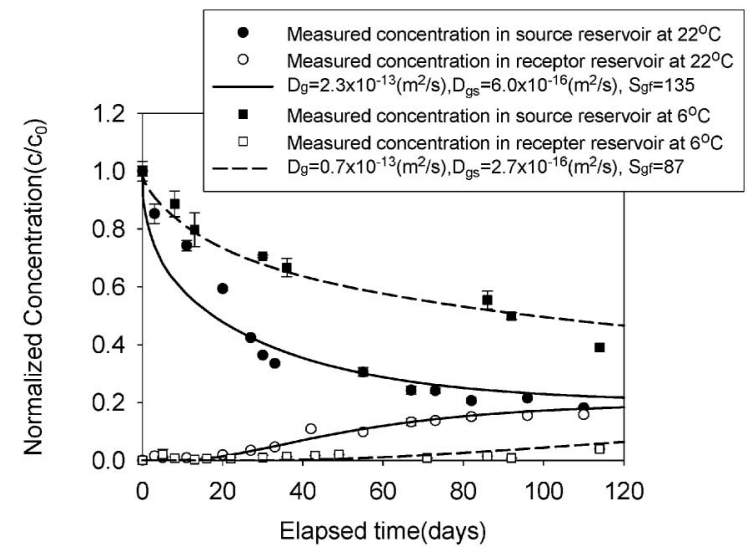

Fig. 10. Variation in toluene concentration in source and receptor cells for a permeation test on a f-HDPE geomembrane at $22^{\circ} \mathrm{C}$ and $6^{\circ} \mathrm{C}$ (mean value and standard deviation of 3 samples)

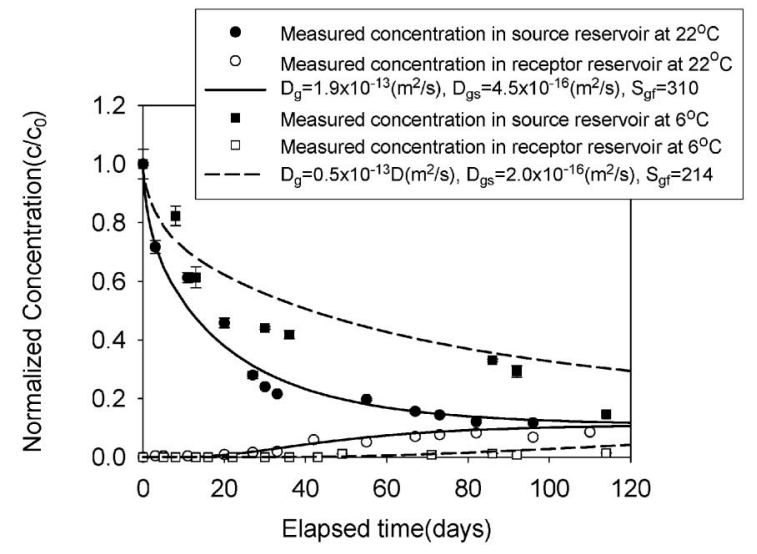

Fig. 11. Variation in ethylbenzene concentration in source and receptor cells for a permeation test on a f-HDPE geomembrane at $22^{\circ} \mathrm{C}$ and $6^{\circ} \mathrm{C}$ (mean value and standard deviation of 3 samples)

branes was slower than for the HDPE geomembranes. This shows that the fluorinated layer decreased mass

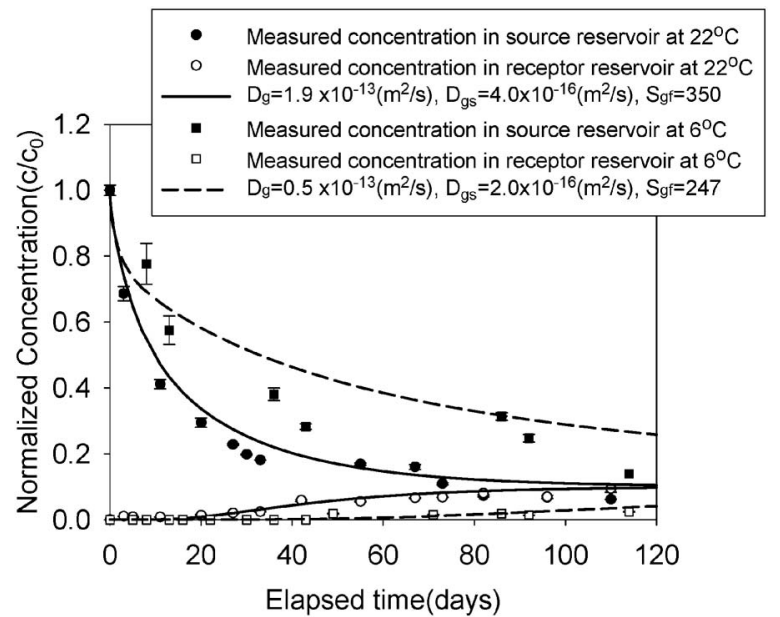

Fig. 12. Variation in $m$ and $p-X y l e n e$ concentration in source and receptor cells for a permeation test on a f-HDPE geomembrane at $22^{\circ} \mathrm{C}$ and $6^{\circ} \mathrm{C}$ (mean value and standard deviation of 3 samples)

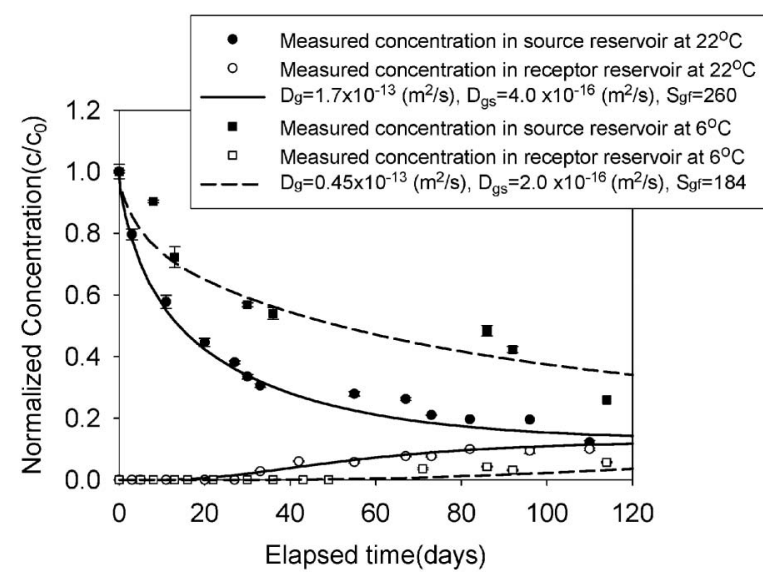

Fig. 13. Variation in $\mathrm{o}$-Xylene concentration in source and receptor cells for a permeation test on a f-HDPE geomembrane at $22^{\circ} \mathrm{C}$ and $6^{\circ} \mathrm{C}$ (mean value and standard deviation of 3 samples)

transport through the geomembrane.

Permeation Parameters, $P_{\mathrm{g}}, P_{\mathrm{gg}}, P_{\mathrm{gf}}$

Theoretical curves (obtained using POLLUTE v7-Rowe and Booker, 2005) were fit to the experimental data to estimate the permeation coefficients for each geomembrane and compound (see Figs. 4-13). The modelling was conducted using the procedure and boundary conditions described by Sangam and Rowe $(2001,2005)$. The HDPE geomembrane was modeled as one layer and the theoretical curve was selected to minimize the sum of the squares of the deviation of the data from the theoretical curve. The f-HDPE geomembrane was modeled as a three layer material (i.e., with a fluorinated layer, HDPE geomembrane and fluorinated layer). Based on both the sorption and diffusion data it was found that the value of $S_{\mathrm{gf}}$ was the same for both the HDPE and f-HDPE (i.e., fluorination did not affect partitioning in a measurable way). Thus the values of $S_{\mathrm{gf}}$ for modelling the f-HDPE were taken to be those obtained from the best fit model- 
Table 5. Parameters obtained from modeling of diffusion tests at $22^{\circ} \mathrm{C}$

\begin{tabular}{cccccccccc}
\hline & $\begin{array}{c}S_{\mathrm{gf}} \\
(-)\end{array}$ & $\begin{array}{c}D_{\mathrm{g}}{ }^{*} \times 10^{13} \\
\left(\mathrm{~m}^{2} / \mathrm{s}\right)\end{array}$ & $\begin{array}{c}D_{\mathrm{gs}} \times 10^{16} \\
\left(\mathrm{~m}^{2} / \mathrm{s}\right)\end{array}$ & $\begin{array}{c}D_{\mathrm{gf}} \times 10^{13} \\
\left(\mathrm{~m}^{2} / \mathrm{s}\right)\end{array}$ & $\begin{array}{c}P_{\mathrm{g}} \times 10^{13} \\
\left(\mathrm{~m}^{2} / \mathrm{s}\right)\end{array}$ & $\begin{array}{c}P_{\mathrm{gf}} \times 10^{13} \\
\left(\mathrm{~m}^{2} / \mathrm{s}\right)\end{array}$ & $\begin{array}{c}P_{\mathrm{gg}} \times 10^{13} \\
\left(\mathrm{~m}^{2} / \mathrm{s}\right)\end{array}$ & $\begin{array}{c}\text { PR } \\
(-)\end{array}$ & $\begin{array}{c}\text { PR Outer layer } \\
(-)\end{array}$ \\
\hline Benzene & 35 & 2.7 & 7.0 & 1.2 & 94.5 & 41 & 0.25 & 2.3 & 395 \\
Toluene & 135 & 2.3 & 6.0 & 1.0 & 311 & 137 & 0.81 & 2.3 & 385 \\
ETB & 310 & 1.9 & 4.0 & 0.74 & 589 & 228 & 1.2 & 2.6 & 475 \\
m and p-Xylene & 350 & 1.9 & 4.0 & 0.74 & 665 & 258 & 1.4 & 2.6 & 475 \\
o-Xylene & 260 & 1.7 & 4.0 & 0.70 & 442 & 183 & 1.0 & 2.4 & 425 \\
\hline
\end{tabular}

* Example: for Benzene $D_{\mathrm{g}} \times 10^{13}\left(\mathrm{~m}^{2} / \mathrm{s}\right)=2.7$ thus $D_{\mathrm{g}}=2.7 \times 10^{-13} \mathrm{~m}^{2} / \mathrm{s}$

$\mathrm{PR}=P_{\mathrm{g}} / P_{\mathrm{gf}}$

PR Outer layer $=P_{\mathrm{g}} / P_{\mathrm{gs}}$

Table 6. Parameters obtained from modeling of diffusion tests at $6^{\circ} \mathrm{C}$

\begin{tabular}{cccccccccc}
\hline & $\begin{array}{c}S_{\mathrm{gf}} \\
(-)\end{array}$ & $\begin{array}{c}D_{\mathrm{g}} \times 10^{13} \\
\left(\mathrm{~m}^{2} / \mathrm{s}\right)\end{array}$ & $\begin{array}{c}D_{\mathrm{gs}} \times 10^{16} \\
\left(\mathrm{~m}^{2} / \mathrm{s}\right)\end{array}$ & $\begin{array}{c}D_{\mathrm{gf}} \times 10^{13} \\
\left(\mathrm{~m}^{2} / \mathrm{s}\right)\end{array}$ & $\begin{array}{c}P_{\mathrm{g}} \times 10^{13} \\
\left(\mathrm{~m}^{2} / \mathrm{s}\right)\end{array}$ & $\begin{array}{c}P_{\mathrm{gf}} \times 10^{13} \\
\left(\mathrm{~m}^{2} / \mathrm{s}\right)\end{array}$ & $\begin{array}{c}P_{\mathrm{gg}} \times 10^{13} \\
\left(\mathrm{~m}^{2} / \mathrm{s}\right)\end{array}$ & $\begin{array}{c}\text { PR } \\
(-)\end{array}$ & $\begin{array}{c}\text { PR Outer layer } \\
(-)\end{array}$ \\
\hline Benzene & 21 & 0.9 & 3.2 & 0.47 & 19 & 10 & 0.067 & 1.9 & 280 \\
Toluene & 87 & 0.65 & 2.7 & 0.36 & 57 & 31 & 0.23 & 1.8 & 240 \\
ETB & 214 & 0.50 & 2.0 & 0.27 & 107 & 58 & 0.43 & 1.8 & 250 \\
m and p-Xylene & 247 & 0.50 & 2.0 & 0.27 & 124 & 67 & 0.49 & 1.8 & 250 \\
o-Xylene & 184 & 0.45 & 2.0 & 0.26 & 83 & 47 & 0.37 & 1.7 & 225 \\
\hline
\end{tabular}

$\mathrm{PR}=P_{\mathrm{g}} / P_{\mathrm{gf}}$

$\mathrm{PR}$ Outer layer $=P_{\mathrm{g}} / P_{\mathrm{gs}}$

ling of the HDPE. Also since the base geomembrane used for the f-HDPE was the same as the HDPE, in modelling the f-HDPE it was assumed that the diffusion coefficient in the core of the geomembrane, $D_{\mathrm{g}}$, was the same as for HDPE and the only unknown to be established from these tests was the diffusion coefficient in the fluorinated layer, $D_{\mathrm{gs}}$. Based on the values of $D_{\mathrm{g}}$ obtained from the analysis of the HDPE geomembrane and $D_{\mathrm{gs}}$ obtained from the 3-layer analysis of the f-HDPE geomembrane, an "equivalent" single layer diffusion coefficient, $D_{\text {gf }}$, was calculated for the f-HDPE geomembrane based on the harmonic mean of the two fluorinated surface layers and the core of the f-HDPE geomembrane. The permeation coefficient for the f-HDPE geomembrane was calculated as $P_{\mathrm{gf}}=S_{\mathrm{gf}} \times D_{\mathrm{gf}}$. The permeation coefficient for the thin fluorinated layer was calculated as $P_{\mathrm{gs}}=S_{\mathrm{gf}} \times D_{\mathrm{gs}}$. Tables 5 and 6 summarize these migration parameters obtained from modeling for permeation experiments conducted for both the HDPE and f-HDPE geomembranes at $22^{\circ} \mathrm{C}$ and $6^{\circ} \mathrm{C}$.

The permeation coefficients, $P_{\mathrm{g}}$, for the HDPE and $P_{\mathrm{gf}}$ for the f-HDPE (Tables 5 and 6) were from greatest to least: $\mathrm{m}$ and $\mathrm{p}$-Xylene $>$ Ethylbenzene $>0$-Xylene $>$ Toluene $>$ Benzene as indicated in Table 5. To illustrate the improvement of the geomembrane due to the application of the fluorinated layer, the permeation ratio $\left(\mathrm{PR}=P_{\mathrm{g}}\right.$ ) $\left.P_{\mathrm{gf}}\right)$ was calculated as the permeation coefficient for HDPE, $P_{\mathrm{g}}$, divided by that for f-HDPE, $P_{\mathrm{gf}}$. For the experiments at $22^{\circ} \mathrm{C}$, the permeation ratio was similar for all compounds considered with an average of 2.4 indicating an approximately $60 \%$ decrease in permeation due to the fluorinated layer. For experiments at $6^{\circ} \mathrm{C}$, the effect of fluorination was similar for all compounds with an average $\mathrm{PR}=1.8$ indicating an approximately $45 \%$ decrease in permeation due to the fluorinated layer. The important role played by the thin outer layer is highlight by the permeation ratio of this outer layer which average about 430 at $22^{\circ} \mathrm{C}$ (i.e., the fluorinated layer provided 430 times the resistance to contaminant migration per unit thickness than the HDPE geomembrane core) and about 250 at $6^{\circ} \mathrm{C}$ (Tables 5 and 6 ).

\section{ARRHENIUS MODELLING FOR $6^{\circ} \mathrm{C}$ EXPERIMENTS}

Arrhenius modeling provides a potential means of predicting the permeation coefficients at other temperatures based on results at room temperature. To do so, however, it is necessary to establish the value of $\theta$ in Eq. (10). Values of $\theta$ were obtained based on the best-fit parameters for each contaminant at the two temperatures and they are given in Tables 7, 8 and 9 for $D_{\mathrm{g}}, D_{\mathrm{gs}}$ and $S_{\mathrm{gf}}$ respectively. The average value of $\theta$ was then deduced for each parameter and then used in Eq. (10) to calculate the value for a given parameter for each contaminant at $6^{\circ} \mathrm{C}$ based on the values at $22^{\circ} \mathrm{C}$ (Tables 7-9). These values were typically within $6 \%$ of the measured values, except for benzene which was a little higher (average 11\% discrepancy). One can estimate the value of $P_{\mathrm{g}}$ and $P_{\mathrm{gf}}$ at a given temperature by first estimating $D_{\mathrm{g}}, D_{\mathrm{gs}}$ and $S_{\mathrm{gf}}$ from Eq. (10) using the appropriate value of $\theta(1.083,1.047$ and 1.026 respectively) as illustrated in Tables 7-9 for $6^{\circ} \mathrm{C}$ and calculating $P_{\mathrm{g}}=S_{\mathrm{gf}} \times D_{\mathrm{g}}$ and $P_{\mathrm{gf}}=S_{\mathrm{gf}} \times D_{\mathrm{gf}}$ from these values. A comparison on the observed and calculated values of $P_{\mathrm{g}}$ and $P_{\mathrm{gf}}$ at $6^{\circ} \mathrm{C}$ is given in Table 10 and it can be seen that the approach yields reasonable results. 
Table 7. Effect of temperature on diffusion coefficient for an HDPE geomembrane

\begin{tabular}{ccccc}
\hline & $\begin{array}{c}\text { Observed } \\
D_{\mathrm{g}} \times 10^{13} \\
\left(\mathrm{~m}^{2} / \mathrm{s}\right) \\
\text { at } 22^{\circ} \mathrm{C}\end{array}$ & $\begin{array}{c}\text { Observed } \\
D_{\mathrm{g}} \times 10^{13} \\
\left(\mathrm{~m}^{2} / \mathrm{s}\right) \\
\text { at } 6^{\circ} \mathrm{C}\end{array}$ & $\theta$ & $\begin{array}{c}D_{\mathrm{g}} \times 10^{13} \\
\left(\mathrm{~m}^{2} / \mathrm{s}\right) \\
\text { a } 6^{\circ} \mathrm{C} \text { based } \\
\text { on } \theta_{\text {average }}^{*}\end{array}$ \\
\hline Benzene & 2.7 & 0.90 & 1.071 & 0.76 \\
Toluene & 2.3 & 0.65 & 1.082 & 0.64 \\
ETB & 1.9 & 0.50 & 1.087 & 0.53 \\
m and p-Xylene & 1.9 & 0.50 & 1.087 & 0.53 \\
o-Xylene & 1.7 & 0.45 & 1.087 & 0.48 \\
\hline
\end{tabular}

$* \theta_{\text {average }}=1.083$

Table 8. Effect of temperature on diffusion coefficient for an f-HDPE geomembrane

\begin{tabular}{ccccc}
\hline & $\begin{array}{c}\text { Observed } \\
D_{\mathrm{gs}} \times 10^{16} \\
\left(\mathrm{~m}^{2} / \mathrm{s}\right) \\
\text { at } 22^{\circ} \mathrm{C}\end{array}$ & $\begin{array}{c}\text { Observed } \\
D_{\mathrm{gs}} \times 10^{16} \\
\left(\mathrm{~m}^{2} / \mathrm{s}\right) \\
\text { at } 6^{\circ} \mathrm{C}\end{array}$ & $\theta$ & $\begin{array}{c}D_{\mathrm{gs}} \times 10^{16} \\
\left(\mathrm{~m}^{2} / \mathrm{s}\right) \\
\text { at } 6^{\circ} \mathrm{C} \text { based } \\
\text { on } \theta_{\text {average }}^{*}\end{array}$ \\
\hline Benzene & 7.0 & 3.2 & 1.050 & 3.4 \\
Toluene & 6.0 & 2.7 & 1.051 & 2.9 \\
ETB & 4.0 & 2.0 & 1.044 & 1.9 \\
m and p-Xylene & 4.0 & 2.0 & 1.044 & 1.9 \\
o-Xylene & 4.0 & 2.0 & 1.044 & 1.9 \\
\hline
\end{tabular}

$* \theta_{\text {average }}=1.047$

Table 9. Effect of temperature on geomembrane partitioning coefficient $S_{\mathrm{gf}}(-)$

\begin{tabular}{ccccc}
\hline & $\begin{array}{c}\text { Observed } \\
S_{\text {gf }} \\
\text { at } 2{ }^{\circ} \mathrm{C}\end{array}$ & $\begin{array}{c}\text { Observed } \\
S_{\text {gf }} \\
\text { at } 6{ }^{\circ} \mathrm{C}\end{array}$ & $\theta$ & $\begin{array}{c}S_{\mathrm{gf}} \text { at } 6^{\circ} \mathrm{C} \\
\text { based on } \\
\theta_{\text {average }}^{*}\end{array}$ \\
\hline Benzene & 35 & 21 & 1.032 & 23 \\
Toluene & 135 & 87 & 1.028 & 90 \\
ETB & 310 & 214 & 1.023 & 207 \\
m and p-Xylene & 350 & 247 & 1.022 & 234 \\
o-Xylene & 260 & 184 & 1.022 & 174 \\
\hline
\end{tabular}

$* \theta_{\text {average }}=1.026$

Table 10. Observed and calculated permeation coefficients $\boldsymbol{P}_{\mathrm{g}}$ and $\boldsymbol{P}_{\mathrm{gf}}$ for HDPE and f-HDPE geomembranes based on Arrhenius predictions for $D_{\mathrm{g}}$ and $D_{\mathrm{gs}} S_{\mathrm{gf}}$, given in Tables 7-9

\begin{tabular}{ccccc}
\hline & $\begin{array}{c}\text { Observed } \\
P_{g} \times 10^{13} \\
\left(\mathrm{~m}^{2} / \mathrm{s}\right) \\
\text { at } 6^{\circ} \mathrm{C}\end{array}$ & $\begin{array}{c}\text { Calculated } \\
P_{\mathrm{g}} \times 10^{13} \\
\left(\mathrm{~m}^{2} / \mathrm{s}\right) \\
\text { at } 6^{\circ} \mathrm{C}\end{array}$ & $\begin{array}{c}\text { Observed } \\
P_{\mathrm{gf}} \times 10^{13} \\
\left(\mathrm{~m}^{2} / \mathrm{s}^{\circ}\right) \\
\text { at } 6^{\circ} \mathrm{C}\end{array}$ & $\begin{array}{c}\text { Calculated } \\
P_{\mathrm{gf}} \times 10^{13} \\
\left(\mathrm{~m}^{2} / \mathrm{s}\right) \\
\text { at } 6^{\circ} \mathrm{C}\end{array}$ \\
\hline Benzene & 19 & 18 & 10 & 10 \\
Toluene & 57 & 58 & 31 & 33 \\
ETB & 107 & 110 & 58 & 57 \\
m and p-Xylene & 124 & 124 & 67 & 65 \\
o-Xylene & 83 & 83 & 47 & 45 \\
\hline
\end{tabular}

\section{DISCUSSION}

\section{HDPE Permeation Parameters and Crystallinity}

Sangam and Rowe (2005) performed permeation tests on $1.5 \mathrm{~mm}$ HDPE and f-HDPE geomembranes with a crystallinity of $61 \%$ and obtained partitioning and diffusion coefficients. Islam and Rowe (2009) conducted per- meation tests using unaged and aged HDPE geomembranes. It is useful to compare the parameters obtained in this study for HDPE geomembrane A with 50\% crystallinity with those obtained by Sangam and Rowe (2005) for HDPE geomembrane B with $61 \%$ crystallinity and Islam and Rowe (2009) for HDPE geomembrane $C$ with 38, $46,54 \%$ crystallinity and geomembrane D with 48,55 and $61 \%$ crystallinity. The diffusion results in each case were performed using similar methodology. Geomembranes A and B came from one manufacturer while geomembranes $\mathrm{C}$ and $\mathrm{D}$ came from another manufacturer. Since the geomembranes were all obtained at different times even those from the same manufacturer do not necessarily have the same resin.

For a given geomembrane, physical aging leads to an increase in crystallinity and this is accompanied by a decrease in the values of the diffusion and sorption parameters (Islam and Rowe 2009 and Table 11; geomembranes $C$ and $D$ ). This may be explained by the fact that, other things being equal, greater crystallinity values indicate a smaller amorphous zone and greater number of impermeable crystals in the geomembrane. Since diffusion is through the amorphous zone, as the crystallinity increases the diffusion and partitioning coefficients will decrease (D'Aniello et al., 2000). However crystallinity alone does not fully define the diffusion characteristics. For example, the diffusion parameters $\left(D_{\mathrm{g}}\right.$ and $\left.S_{\mathrm{gg}}\right)$ for geomembrane B with a virgin crystallinity of $61 \%$ are substantially higher than for geomembrane $\mathrm{D}$ when it had been aged to $61 \%$ crystallinity. While some of the difference may be attributed to uncertainty and limitations of the method for establishing diffusion parameters, there is a clear difference for all the contaminants examined. Also geomembrane A with a crystallinity of $50 \%$ had diffusion coefficients very similar (except for benzene) to those for virgin geomembrane $\mathrm{C}$ at $38 \%$ crystallinity. Thus it would appear that the diffusion parameters may be related to both differences in the arrangements of the crystals and cross-linking as well as the number (proportion) of crystals as defined by the crystallinity. Table 11 clearly illustrates that even for a given geomembrane there are no unique diffusion parameters (they vary with time as the geomembrane experiences physical aging) and that there are difference for different geomembranes even from the same manufacturer. However these results also give an indication of the range of values that might be encountered (Table 12).

\section{Effect of Fluorination}

The results obtained from the current study of f-HDPE geomembrane A can be compared with those for the f-HDPE geomembrane B examined by Sangam and Rowe (2005). There are two primary differences between the two geomembranes. First, the crystallinity and the diffusion parameters of the base geomembrane are different (Table 13). Second, the geomembrane examined herein had a fluorine thickness of 1-4 $\mu \mathrm{m}$ with an average of $2.5 \mu \mathrm{m}$ whereas the geomembrane examined by Sangam and Rowe (2005) had a fluorinated layer thickness of 1-5 
Table 11. Diffusion and sorption coefficients and crystallinity obtained from references

\begin{tabular}{|c|c|c|c|c|c|c|c|c|c|c|c|c|c|c|c|c|}
\hline Geomembrane & \multicolumn{2}{|c|}{$\mathrm{A}^{(\mathrm{a})}$} & \multicolumn{2}{|c|}{$\mathrm{B}^{(\mathrm{b})}$} & \multicolumn{2}{|c|}{$\mathrm{C}^{(\mathrm{c})}$} & \multicolumn{2}{|c|}{$\mathrm{C}^{(\mathrm{d})}$} & \multicolumn{2}{|c|}{$C^{(\mathrm{e})}$} & \multicolumn{2}{|c|}{$D^{(f)}$} & \multicolumn{2}{|c|}{$D^{(g)}$} & \multicolumn{2}{|c|}{$\mathrm{D}^{(\mathrm{h})}$} \\
\hline Crystallinity & \multicolumn{2}{|c|}{$50 \%$} & \multicolumn{2}{|c|}{$61 \%$} & \multicolumn{2}{|c|}{$38 \%$} & \multicolumn{2}{|c|}{$46 \%$} & \multicolumn{2}{|c|}{$54 \%$} & \multicolumn{2}{|c|}{$48 \%$} & \multicolumn{2}{|c|}{$55 \%$} & \multicolumn{2}{|c|}{$61 \%$} \\
\hline Parameters & $\begin{array}{c}D_{\mathrm{g}} \times 10^{13} \\
\left(\mathrm{~m}^{2} / \mathrm{s}\right)\end{array}$ & $\stackrel{S_{\mathrm{gf}}}{(-)}$ & $\begin{array}{c}D_{\mathrm{g}} \times 10^{13} \\
\left(\mathrm{~m}^{2} / \mathrm{s}\right)\end{array}$ & $\underset{(-)}{S_{\mathrm{gf}}}$ & $\begin{array}{c}D_{\mathrm{g}} \times 10^{13} \\
\left(\mathrm{~m}^{2} / \mathrm{s}\right)\end{array}$ & $\stackrel{S_{\mathrm{gf}}}{(-)}$ & $\begin{array}{c}D_{\mathrm{g}} \times 10^{13} \\
\left(\mathrm{~m}^{2} / \mathrm{s}\right)\end{array}$ & $\stackrel{S_{\mathrm{gf}}}{(-)}$ & $\begin{array}{c}D_{\mathrm{g}} \times 10^{13} \\
\left(\mathrm{~m}^{2} / \mathrm{s}\right)\end{array}$ & $\stackrel{S_{\mathrm{gf}}}{(-)}$ & $\begin{array}{c}D_{\mathrm{g}} \times 10^{13} \\
\left(\mathrm{~m}^{2} / \mathrm{s}\right)\end{array}$ & $\underset{(-)}{S_{\mathrm{gf}}}$ & $\begin{array}{c}D_{\mathrm{g}} \times 10^{13} \\
\left(\mathrm{~m}^{2} / \mathrm{s}\right)\end{array}$ & $\underset{(-)}{S_{\mathrm{gf}}}$ & $\begin{array}{c}D_{\mathrm{g}} \times 10^{13} \\
\left(\mathrm{~m}^{2} / \mathrm{s}\right)\end{array}$ & $\underset{(-)}{S_{\mathrm{gf}}}$ \\
\hline Benzene & 2.7 & 35 & 2.0 & 60 & 2.4 & 55 & 1.8 & 45 & 1.4 & 35 & 1.9 & 50 & 1.5 & 40 & 1.3 & 30 \\
\hline Toluene & 2.3 & 135 & 2.2 & 140 & 2.2 & 125 & 1.8 & 100 & 1.4 & 80 & 1.9 & 100 & 1.5 & 80 & 1.1 & 60 \\
\hline Ethylbenzene & 1.9 & 310 & 1.6 & 260 & 1.8 & 345 & 1.4 & 300 & 1.1 & 230 & 1.6 & 310 & 1.2 & 270 & 0.9 & 230 \\
\hline $\mathrm{m}$ and $\mathrm{p}$-Xylene & 1.9 & 350 & 1.5 & 300 & 1.7 & 440 & 1.3 & 350 & 1.0 & 260 & 1.5 & 340 & 1.1 & 290 & 0.8 & 250 \\
\hline o-Xylene & 1.7 & 260 & 1.1 & 250 & 1.7 & 320 & 1.2 & 290 & 0.9 & 235 & 1.4 & 295 & 1.1 & 255 & 0.8 & 220 \\
\hline
\end{tabular}

(a) This study, (b) Sangam and Rowe $2005^{\text {(c)-(h) }}$ Islam and Rowe 2009. (c) and (f) are for virgin samples of geomembranes C and D respectively, (d),(e),(g),(h) are for samples aged for different periods of time at $85^{\circ} \mathrm{C}$ : (d) geomembrane $\mathrm{C}$ after 13 months, (e) geomembrane $\mathrm{C}$ after $32 \mathrm{months}$,

${ }^{(\mathrm{g})}$ geomembrane D after 10 months and ${ }^{\text {(h) }}$ geomembrane D after 25 months.

Table 12. Range of values for BTEX diffusion parameters at room temperature obtained for different HDPE geomembranes using the same methods

\begin{tabular}{cccc}
\hline & $\begin{array}{c}S_{\mathrm{gf}} \\
(-)\end{array}$ & $\begin{array}{c}D_{\mathrm{g}} \times 10^{13} \\
\left(\mathrm{~m}^{2} / \mathrm{s}\right)\end{array}$ & \multicolumn{1}{c}{$\begin{array}{c}P_{\mathrm{g}} \times 10^{13} \\
\left(\mathrm{~m}^{2} / \mathrm{s}\right)\end{array}$} \\
\hline Benzene & $30-60$ & $1.3-2.7$ & $40-130$ \\
Toluene & $60-135$ & $1.1-2.3$ & $70-310$ \\
ETB & $230-345$ & $0.9-1.9$ & $210-620$ \\
m and p-Xylene & $260-440$ & $0.8-1.9$ & $200-750$ \\
o-Xylene & $220-320$ & $0.8-1.7$ & $180-550$ \\
\hline
\end{tabular}

Table 13. Values for BTEX diffusion parameters at room temperature obtained for f-HDPE geomembranes

\begin{tabular}{crccccc}
\hline & \multicolumn{3}{c}{$\begin{array}{c}\text { Present study } \\
\text { Geomembrane A }\end{array}$} \\
\hline Crystallinity & \multicolumn{3}{c}{$54 \%$} & \multicolumn{3}{c}{$\begin{array}{c}\text { Sangam and Rowe (2005) } \\
\text { Geomembrane B }\end{array}$} \\
\hline & $\begin{array}{r}S_{\mathrm{gf}} \\
(-)\end{array}$ & $\begin{array}{c}D_{\mathrm{gf}} \times 10^{13} \\
\left(\mathrm{~m}^{2} / \mathrm{s}\right)\end{array}$ & $\begin{array}{c}P_{\mathrm{gf}} \times 10^{13} \\
\left(\mathrm{~m}^{2} / \mathrm{s}\right)\end{array}$ & $\begin{array}{c}S_{\mathrm{gf}}(-) \\
D_{\mathrm{gf}} \times 10^{13} \\
\left(\mathrm{~m}^{2} / \mathrm{s}\right)\end{array}$ & $\begin{array}{c}P_{\mathrm{gf}} \times 10^{13} \\
\left(\mathrm{~m}^{2} / \mathrm{s}\right)\end{array}$ \\
\hline Benzene & 35 & 1.2 & 41 & 60 & 0.76 & 45 \\
Toluene & 135 & 1.0 & 137 & 140 & 0.62 & 87 \\
ETB & 310 & 0.74 & 228 & 260 & 0.36 & 94 \\
m and p-Xylene & 350 & 0.74 & 258 & 300 & 0.33 & 99 \\
o-Xylene & 260 & 0.70 & 183 & 250 & 0.28 & 70 \\
\hline
\end{tabular}

$\mu \mathrm{m}$ but with an average of $4 \mu \mathrm{m}$.

When examining the permeation coefficient for the fluorinated geomembrane, it was found that the permeation coefficients established by Sangam and Rowe (2005) were substantially lower than those established herein for all contaminants except benzene as indicated by the range of $P_{\mathrm{gf}}$ values given in Table 13. This may be partly due to the difference in base geomembrane-but only partly. The permeation ratio PR indicates the improvement in performance of the given geomembrane due to fluorination. A comparison of the average permeation ratio's ( $\mathrm{PR}=2.4$ for geomembrane $\mathrm{A}$ and $\mathrm{PR}=3.8$ for geomembrane $\mathrm{B}$ ) shows a $60 \%$ improvement in performance of geomembrane $\mathrm{B}$ compared to geomembrane $\mathrm{A}$ due to fluorination. This is considered to be at least partially due to the thicker average fluorinated layer $(4.0 \mu \mathrm{m})$ for geomembrane B than for geomembrane A $(2.5 \mu \mathrm{m})$. To illustrate the effect of the thickness of fluorine layer, analyses

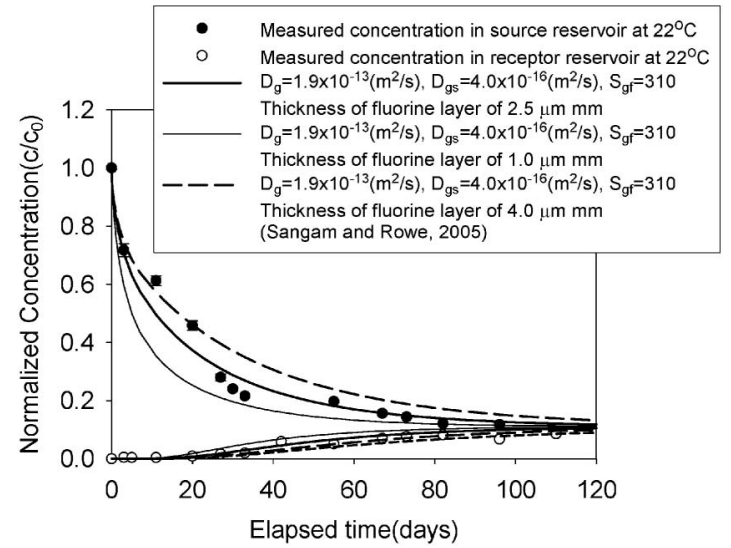

Fig. 14. Evaluation of fluorinated layer of f-HDPE geomembrane at $22^{\circ} \mathrm{C}$ (ETB)

were performed for f-HDPE geomembrane and ethylbenzene for the average thickness $(2.5 \mu \mathrm{m})$ and the upper $(4$ $\mu \mathrm{m})$ and lower $(1 \mu \mathrm{m})$ bound thicknesses. The fluorinated layer thickness has a significant effect on the mass transport both into and through the geomembrane (see Fig. 14). Based on the parameters given in Table 5, the permeation coefficient can be calculated assuming that the fluorinated layer had the same average thickness as for geomembrane B $(4 \mu \mathrm{m})$ and the corresponding permeation ratio would increase by almost $40 \%$ to 3.3 . The remaining difference in the permeation through the two f-HDPE geomembranes may be attributed the lower diffusion coefficient in the fluorinate layer for geomembrane $\mathrm{B}$ relative to geomembrane $\mathrm{A}$.

These results highlight the importance of both the consistency of the fluorination process that would be required to consistently reduce the permeation of BTEX as well as the need to minimize scratching of the geomembrane in the field to minimize damage to the thin fluorinated layer in field applications.

\section{Prediction of Permeation Parameters due to a Change in Temperature}

Previous studies have indicated that an Arrhenius relationship may be used to predict diffusion coefficients of geomembranes at a second temperature (Crank and 
Park, 1968; Schnoor, 1996; Aminabhavi and Naik, 1998). Rowe et al. (2005) discussed the effect of temperature on diffusion and sorption of BTEX to geosynthetic clay liners and concluded that the change in diffusion coefficient due to a change in temperature dominates over the effect of the change in partitioning coefficient. A similar conclusion can be reached for the geomembrane studied herein with the value of the Arrhenius parameter $\theta$ (Eq. (10)) being 1.083 for $D_{\mathrm{g}}, 1.047$ for $D_{\mathrm{gs}}$ and only 1.026 for $S_{\mathrm{gf}}$. These values of $\theta$ can be used in Eq. (10) to estimate these parameters at temperatures between $22^{\circ} \mathrm{C}$ and $6^{\circ} \mathrm{C}$.

\section{CONCLUSIONS}

The effectiveness of the fluorination layer and the effect of temperature were examined for both $1.5 \mathrm{~mm}$ HDPE and f-HDPE geomembranes at temperatures of $22^{\circ} \mathrm{C}$ and $6^{\circ} \mathrm{C}$. The partitioning coefficient obtained from sorption/immersion test was shown to be effectively the same as that from desorption test. The thickness of the fluorinated layer on the f-HDPE geomembranes ranged between 1-4 $\mu \mathrm{m}$ with an average value of $2.5 \mu \mathrm{m}$. The diffusion, permeation coefficients and permeation reduction were evaluated for both HDPE and f-HDPE geomembranes.

The permeation coefficients of f-HDPE geomembrane at room temperature were significantly less than those for the conventional HDPE (by a factor of about 2.4). The permeation ratio indicates the improvement in performance of a geomembrane due to fluorination. The effect of fluorination was greater at room temperature $(\mathrm{PR}=$ 2.4) than at $6^{\circ} \mathrm{C}(\mathrm{PR}=1.8)$. The Arrhenius parameter $\theta$ of 1.083 for the diffusion coefficient for the base geomembrane, 1.047 for the diffusion coefficient for fluorinated layer and 1.026 for the partitioning coefficient can be used to estimate these parameters at temperatures between $22^{\circ} \mathrm{C}$ and $6^{\circ} \mathrm{C}$.

A comparison of the average permeation ratio's (at room temperature) of $\mathrm{PR}=2.4$ for the geomembrane studied herein with $\mathrm{PR}=3.8$ for the geomembrane examined by Sangam and Rowe (2005) shows 60\% better performance due to fluorination for the f-HDPE examined by Sangam and Rowe (2005). Calculations indicate that two thirds of this difference can be attributed to the thicker average fluorinated layer $(4.0 \mu \mathrm{m})$ for Sangam and Rowe's geomembrane compared with the present geomembrane $(2.5 \mu \mathrm{m})$. The remaining difference in the permeation ratio for the two f-HDPE geomembranes may be attributed the lower diffusion coefficient in the fluorinate layer obtained for Sangam and Rowe's geomembrane.

Thus while fluorination can significantly increase the diffusive flux of BTEX through a geomembrane, it the thickness of the fluorinated layer and the consistency of the fluorination process greatly influence the effectiveness of $\mathrm{f}-\mathrm{HDPE}$ in reducing the permeation of BTEX. It also follows that in the use of these material considerable care will be needed to minimize scratching of the thin fluorinated layer in field applications if optimal performance is to be realized.

\section{ACKNOWLEDGEMENTS}

The study was financially supported by the Natural Science and Engineering Research Council of Canada (NSERC) and the North Warning System Office, Department of National Defence, Canada. Their support throughout the project is gratefully acknowledged. The authors acknowledge Surface Science Western for data regarding the thickness of the fluorinated layers. The research was conducted on equipment funded by the Canada Foundation for Innovation and the Ontario Ministry of Research and Innovation.

\section{REFERENCES}

1) Aminabhavi, T. M. and Naik, H. G. (1998): Chemical compatibility testing of geomembranes-sorption/desorption, diffusion, permeation and swelling phenomena, Geotextiles and Geomembranes, 16, 333-354.

2) Anand, M., Hobbs, J. P. and Brass, I. J. (1994): Surface fluorination of polymers, Organofluorine Chemistry: Principles and Commercial Applications, (eds. by Banks, R. E., Smart B. E. and Tatlow J. C.), Plenum Press, 469-481.

3) Bathurst, R. J., Rowe, R. K., Zeeb, B. and Reimer, K. (2006): A geocomposite barrier for hydrocarbon containment in the Arctic, International Journal of Geoengineering Case Histories, 1(1), 18-34.

4) Brachman, R. W. I. and Sabir, A. (2010): Geomembrane puncture and strains from stones in an underlying clay layer, Geotextiles and Geomembranes, 28(4), 335-343.

5) Crank, J. (1975): The Mathematics of Diffusion, 2nd edition, Clarendon Press, 1-349.

6) Crank, J. and Park, J. (1968): Diffusion in Polymers, Academic Press, 1-425.

7) D'Aniello, C., Guadagno, L., Gorrasi, G. and Vittoria, V. (2000): Influence of the crystallinity on the transport of isotactic polypropylene, Polymer, 41, 2512-2519.

8) Edil, T. B. (2003): A review of aqueous-phase VOC transport in modern landfill liners, Waste Management, 23, 561-571.

9) Islam, M. Z. and Rowe, R. K. (2009): Permeation of BTEX through unaged and aged HDPE geomembranes, ASCE, Journal of Geotechnical and Geoenvironmental Engineering, 135(8), 11301140.

10) Koerner, R. M., Hsuan, Y. G., Koerner, G. R. and Gryger, D. (2010): Ten year creep puncture study of HDPE geomembranes protected by needle-punched nonwoven geotextiles, Geotextiles and Geomembranes, 28(6), 503-513.

11) McWatters, R. and Rowe, R. K. (2010): Diffusive transport of VOCs through LLDPE and two Co-Extruded Geomembranes, ASCE, Journal of Geotechnical and Geoenvironmental Engineering, 136(9), 1167-1177.

12) Mitchell, J. K., Alvarez-Cohen, L., Atekwana, E., Burns, S. E., Gilbert, R. B., Kavazanjian, E., O’Riordan, W. H., Rowe, R. K., Shackelford, C. D., Sharma, H. D. and Yesiller, N. (2007): Assessment of the performance of engineered waste containment barriers, Report of the Committee to Assess the Performance of Engineered Barriers to National Research Council of the U.S. National Academies, ISBN-13: 978-0-309-10809-6 (121).

13) Mohr, J. M., Paul, D. R., Mlsna, T. E. and Lagow, R. J. (1991a): Surface fluorination of composite membranes. Part I. Transport properties, Journal of Membrane Science, 55, 131-148.

14) Mohr, J. M., Paul, D. R., Mlsna, T. E. and Lagow, R. J. (1991b): Surface fluorination of composite membranes. Part II. Characterization of the fluorinated layer, Journal of Membrane Science, 55, $149-171$. 
15) Park, J. K. and Nibras, M. (1993): Mass flux of organic chemicals through polyethylene geomembranes, Water Environment Research, 65, 227-237.

16) Rowe, R. K. (1998): Geosynthetics and the minimization of contaminant migration through barrier systems beneath solid waste, Keynote Lecture, Proceedings of the 6th International Conference on Geosynthetics, Industrial Fabrics Association International, 27-102.

17) Rowe, R. K. (2005): Long-term performance of contaminant barrier systems, Geotechnique, 55(9), 631-678.

18) Rowe, R. K. and Booker, J. R. (2005): POLLUTE v.7.0_1D Pollutant Migration through a Composite Liner System (C) 1983, 1990, 1994, 1997, 2005. Distributed by GAEA Technologies Ltd.

19) Rowe, R. K., Quigley, R. M., Brachman, R. W. I. and Booker, J. R. (2004): Barrier Systems for Waste Disposal Facilities, E and FN Spon, 587.

20) Rowe, R. K., Mukunoki, T. and Sangam, P. H. (2005): BTEX diffusion and sorption for a geosynthetic clay liner at two temperatures, ASCE, Journal of Geotechnical and Geoenvironmental Engineering, 131(10), 1211-1221.

21) Row, R. K., Rimal, S. and Sangam, H. P. (2009): Ageing of HDPE geomembrane exposed to air, water and leachate at different temperatures, Geotextiles and Geomembranes, 27(2), 131-151.

22) Rowe, R. K., Rimal, S., Arnepalli, D. N. and Bathurst, R. J. (2010): Durability of fluorinated high density polyethylene geomembrane in the Arctic, Geotextiles and Geomembranes, 28(1), 100-107.

23) Sangam, H. P., Rowe, R. K. Kastelic, J. R. and Cadwallader, M. (2001): Effects of HDPE geomembrane fluorination on the diffusive migration of MSW organic contaminants, Proceedings of Geosynthetics 2001, 163-176.

24) Sangam, H. P. and Rowe, R. K. (2001): Migration of dilute aqueous organic pollutants through HDPE geomembranes, Geotextiles and Geomembranes, 19, 329-357.

25) Sangam, H. P. and Rowe, R. K. (2005): Effect of surface fluorination on diffusion through an HDPE geomembrane, ASCE, Journal of Geotechnical and Geoenvironmental Engineering, 131(6), 694-704.

26) Schnoor, J. L. (1996): Environmental Modeling Fate and Transport of Pollutants in Water, Air, and Soil, John Wiley and Sons, Inc., 96-98. 